\title{
Angst in Rainer Maria Rilke's Duino Elegies
}

\author{
Amechi Nicholas Akwanya \\ Department of English \& Literary StudiesUNN
}

\begin{abstract}
Rilke's Duino Elegies is rarely studied as one work. There are studies of some individual Elegies, especially the First and the Second, which are undoubtedly extraordinarily powerful poems. But the power of the whole is not dependent on these alone or on the few others which are also discussed. What is attempted in this paper is a study of the set as one work of art. Close reading of the poems hereis guided by the question, what is the loss or the wrack of which the poem as a whole or in its individual parts is the response; and itreveals a character with an anguished state of consciousness regarding his place in the world. The analysis of the Speaker's condition is based on concepts derived from Heidegger's Being and Time, mainly Angst and Sorge. But there is need first of all to pin down this Speaker and to characterize him. A grammatical analysis is undertaken in this paper for that purpose.
\end{abstract}

Key concepts:Angst, consciousness, disclosedness, dramatic monologue, hero, soliloquy, Sorge, transference.

\section{Introduction}

The Speaker in Duino Elegies is a forceful presence, and may be discussed with each poem individually as part of its constitution or with the whole series of ten poems where what appears to be one and the same voice persists. Images succeed one another in the unfolding of the poems, but one and the same voice announces and characterizes them all. Some of the images, like the Angel, appear more than once in the different poems and although they may be associated with a capacity to affect other existents in the poem in one way or another, they are always represented; that is, in the discourse of the Speaker, whose perspective is shifting from moment to moment. The Speaker is therefore the real presence in the poem; and how he sees what he sees is what matters, not what the thing may be in itself. Little or no attention has been paid to this Speaker in criticism of Duino Elegies; and one of the consequences is that these poems are generally 'not regarded as a fully coherent project' (Ryan2004: 3). Part of the motivation of this paper is to determine to what extent they can be read as making up one universe.

The perceptions and the voice seem to me to be modulated by what HeideggercallsAngst, which is an "existential 'not-being-at-home with one's self" (Nichols 2000). It is this angst that gives us insight into the nature of the Speaker's mind; for angst is connected with disclosure, in fact "one of the most far reaching and most primordial possibilities of disclosure" (Nichols). This concept of disclosurealso describes the career of the images we have already referred to in the poem: they come into "disclosedness" to the Speaker, who then announces what he perceives. This disclosedness is self-sufficient truth - "Heidegger's preferred translation of the Greek ... aletheia, "truth"” (Schuwer and Rojcewicz 1992: xiv). This paper is not really a philosophical reading of the Elegies, for as Venkatchalam has warned us, "Just because a certain literary text incorporates philosophical questions or just because a philosophical work uses literary devices or examples does not mean that they have successfully liquidated their distinctness" ("In Search of Definitions: Literature and Philosophy"n.p). It will rather attempt a close reading of the Elegies, exploring the Speaker's"not-being-athome withone's self'as a precondition for attaining the poems' self-disclosure. It is a question of understanding the poem, not reality or truth or some philosophical category.

\section{Anguished Situation of the Speaker}

The Speaker's individuality is problematized in the first movement of Elegy the First, where it is both individual and plural. Thus it is impossible to determine if we are dealing with one single individual's experience or a universal experience. What is clear is that this subjectivity is in a state of fear and unease. We read,

beauty is nothing but

the beginning of terror, that we are still able to bear, and we revere it so, because it calmly disdains to destroy us. Every Angel is terror.

And so I hold myself back and swallow the cry

of a darkened sobbing. Ah, who then can 
we make use of? Not Angels: not men,

and the resourceful creatures see clearly

that we are not really at home

in the interpreted world.

The purpose for which he wants to make use of some oneis not here stated, although there is a sense of a deeply felt need in the Second Elegy for something to give meaning to existence. Between two orders of life surrounding the human, the angelicand the resourceful creatures', he finds himself isolated. He does speak in the plural, as if with the voice of the whole of humanity: "Ah, who then can / we make use of?"Buthe is recounting a painful emotional state, which is not shared with the rest of humanity: "And so I hold myself back and swallow the cry / of a darkened sobbing". To this extent he is also far from the rest of humanity: he is strictly an outsider. Psychologically, he is in a state ofangst. He is "not really at home / in the interpreted world". First, he is not at home; second, he is in "the interpreted", not the real world; and he is alienated from his own interpretation. In this "interpreted world", beauty exercises intentionality: "it calmly disdains / to destroy us". Everything seems capable of exceeding its natural limits. The subject, however, must restrain himself and hold back his very emotions.

The shiftiness of this Speaker is one reason for the elusiveness that has often been remarked about these poems (see Krauss 2005). This shiftiness is primarily a grammatical question. Now he speaks in the first person singular; then he speaks in the plural; forhe is the "expansive" persona of modernism (MacKay 1987: 150), whose peculiar mode of consciousness is seen in The Collected Letters of D.H. Lawrenceas:

another ego, according to whose actionthe individual is unrecognizable, and passes through, as it were, allotropicstateswhich it needs a deeper sense than any we've been usedto exercise, to discover are states of the same single radically unchanged element(qtd in MacKay 207)

Not only is this subjectivity "throbbing", like Tiresias in The Waste Land, between singularity and plurality, it is also schizoid and addresses itself in a one-sided dialogue, as in the following:

Yes, the Spring-times needed you deeply. Many a star

must have been there for you so you might feel it. A wave

lifted towards you out of the past, or, as you walked

past an open window, a violin

gave of itself. All this was their mission.

But could you handle it? Were you not always,

still, distracted by expectation, as if all you experienced,

like a Beloved, came near to you? (First Elegy)

Just as this subjectivity can shift freely from the singular to the plural first person, so it can shift from first to second person, and back again. These three grammatical persons whose distinctness is so crucial for discourse freely exchange identities in the Elegies. It is necessary to track their movements in order to see the work in its full disclosedness. Such an exchange takes place between the you and the me/I of the following passage:

Or else an inscription exaltedly impressed itself on you,

as lately the tablet in Santa Maria Formosa.

What do they will of me? That I should gently remove

the semblance of injustice, that slightly, at times,

hinders their spirits from a pure moving-on.

The personal pronouns associated with the voice in the poems areclearly not configured to the real, nor does their shiftiness thereby"disengage subjectivity from its essence" (Levinas 1978: 9). Their function is purely tactical, and determined by the discursive needs of the poem. But as the second person you grammatically pertains to the other in a discursive relation, by its deployment the subject ventures farthest into the field of the other.

But this is a grammatical effect. The subject still knows itself in opposition to other things, the Springtimes, the star, the wave, the violin, and the tablet which go out of their way to find him, so that experience is a matter of becoming aware of the intentional motions and playful visitations of these events and inanimate objects towards oneself. On the other hand, theother does appear on occasions, where one must appeal to the emergent rhetorical patterns for a distinction. In the following, the Archangel is directly addressed: 
Let the Archangelnow, the dangerous one, from behind the stars, take a single step down and toward us: our own heart, beating on high would beat us down. What are you?

Early successes, Creation's favourite ones, mountain-chains, ridges reddened by dawns of all origin - pollen of flowering godhead, junctions of light, corridors, stairs, thrones, spaces of being, shields of bliss, tempests of storm-filled, delighted feeling and, suddenly, solitary mirrors: gathering their own out-streamed beauty back into their faces again (Second Elegy).

The second person here is the youof dramatic monologue, breaking with the more or lesssustained soliloquy of the poetry. Where such a dramatic monologue occurs in the Third Elegy, it gives rise to a further transformation in which subjectivity shifts to the third person:

Mother, you made his littleness: you were the one who began him.

In Freud, the phrase is "his majesty, the ego", the hero of dreams. "His littleness" in the above verse both plays upon the delicateness of the young life and substitutes a lowly image, alienated in the third person, for the expected ego ideal. But it is not a totally self-effacing act, since he is actually calling upon the mother to turn her attention once again to that delicate and tender being wholly dependent on her love and care for his very survival, around whom her life once revolved. Care (Sorge) is another Heideggerian concept elucidated in Being and Time and closely related to Angst.Both are positive terms and characterize human life. He writes that,"As a possibility of being of Da-sein, together with the Da-seinitself disclosed in it, Angst provides the phenomenal basis for explicitly grasping the primordial totality of being of Da-sein. Its being reveals itself as care"(171).

Da-sein, loosely translated as "human existence" (Audi 1999: 371), is kept in openness to the world by Angst and projects itself upon its objects through care. In Heidegger's own words:

Da-sein has a mode of being in which it is brought before itself and itis disclosed to itself in its throwness. But throwness is the mode of beingof a being which always is itself its possibilities in such a way that itunderstands itself in them and from them (projects itself upon them) (Being and Time 169).

"His littleness" is not just this very young and delicate human being: in and through him, the Mother understands herself. "His littleness" is in fact what confers identity on the Mother. The dramatic monologue brings this to the Mother's attention. The gap between the Speaker and "his littleness" can be closed: they are one and the same essence. But that between the youof the soliloquy and that of the monologue is based on essential difference between subjectivity and objectivity.

In these poems, whatever has object status has stability and seems to be capable of transcendence: the birds can attain "more intimate flight"; the arrowcan become "in its flight, / something more than itself"; the hero "prolongs himself, even his falling / was only a pretext for being, his latest rebirth"; the saints can attain such "listening" that not even the mighty call raised "from the earth" can get their attention; and "in the grieving for Linos, / first music ventured to penetrate arid rigidity". By contrast, in the soliloquy with the Archangel stepping out from behind the stars, the angels are literally irreducible. Even though beauty may stream out of them, they lose nothing, but gather "their own out-streamed beauty / back into their faces again". Objective status curiously places things beyond the ravages of temporality, whereas the subject is at risk and anguished by this fact.

The poem's meditation also has in view the making sense of this disparity. With regard to angels, they are "Early successes, Creation'sfavourite ones" and pure essences beyond the influence of other creatures. As to animal creatures who share the world with the human, they exist in freedom - not having consciousness, and also, paradoxically, not being under the rule of death:

We know what is outside us from the animal's

face alone: since we already turn

the young child round and make it look

backwards at what is settled, not that openness

that is so deep in the animal's vision. Free from death.

We alone see that: the free creature

has its progress always behind it, 
and God before it, and when it moves, it moves

in eternity, as streams do.

We never have pure space in front of us,

not for a single day, such as flowers open

endlessly into. Always there is world,

and never the Nowhere without the Not: the pure,

unwatched-over, that one breathes and

endlessly knows, without craving (Eight Elegy).

The first person plural here is not the sort of tactical move we have discussed. It calls into play, by way of a signified, human existence itself, which is in the proper sense of the word, in the world, watched over by death, and burdened by consciousness and memory.Unlike the "free creature" with "its progress always behind it", the human creature by virtue of nurture reflects, looking "backwards at what is settled". With him, therefore, there is no "pure space in front"; there can be no "pure moving-on". What it sees ahead is with a perspective, presumably through what is past and settled.

The "openness ... so deep in the animal's vision" is fully accounted for in Elegy Eight, where we read,

that an animal

mutely, calmly is looking through and through us....

If there was consciousness like ours

in the sure creature, that moves towards us

on a different track - it would drag us

round in its wake. But its own being

is boundless, unfathomable, and without a view

of its condition, pure as its outward gaze.

And where we see future it sees everything,

and itself in everything, and is healed for ever.

The animal's being is boundless and unfathomable; consequently, the animal is not properly in the world: it is a "sure creature"; possibility is not part of its identity as a creature; which means that it is free from angst, as well as care. For example,it lacks the possibility of becoming careworn, which requires both consciousness and memory a sense of the future towards which the human is irremediably thrown.

\section{Temporality}

Being in the world is also to be time-bound; and this is a factor of angst for the Speaker. The Angel obviously exists outside temporality, since his existence is behind the stars. It is to be expected that stepping out from behind these stars and venturing into the world would not fail of its effect on that being. The Speaker cites the biblical story of Tobias,

when one of the most radiant of you stood at the simple threshold, disguised somewhat for the journey and already no longer awesome (Like a youth, to the youth looking out curiously).

If the Angel may have cause to share in human experience, humans also long to reach beyond the limits of their time and space. In Heidegger's philosophy, human existence is not limited to actuality; there is also a potentiality which is essential to it and weighs for him even more than what is actual. By its nature, human existenceis subject to modification by forces outside itself, but it can also assign itself a goal, give itself an orientation, and the motivation to achieve it. Such is the possibility of transcendence. He writes,

As a being, Da-sein always defines itself in terms of a possibility which it is and somehow understands in its being. That is the formal meaning of the constitution of the existence of Da-sein. But for the ontological interpretation of this being, this means that the problematic of its being is to be developed out of the existentiality of its existence (41).

As a poetic form, an elegy never fails to inscribe the loss that calls it into being, like the "Dear lovely bowers of innocence and ease" of Goldsmith'sThe Deserted Village, or the wrack it endures, like that arising from the decease of the "genial current of the soul" and man's"useful toil" in Gray'sElegyWritten in the Country Churchyard.Rilke'sDuino Elegies does not directly name the state of affairs it laments, leading readers like Santner to conclude that these are "second-order elegies: elegies for the passing of the space in which elegy is 
still possible"(2006:49). But considering the subject's inability to find a footing anywhere,one may formulate the wrack in Duino Elegies in Heideggerian terms, namely "the problematic of the world" (Being and Time93): real contact with this world is elusive to the subject, and at the same time human longing for transcendence is always already defeated by virtue of being in the world.For human creatures, transcendence would boil down to attempting to breakout of the limitations imposed by temporality and escape "what often / overwhelms us - a memory" (Eight Elegy). It is a hopeless and unrealizable longing:

Then up the stairway, the stairway of calling, up to

the dreamed-of temple of future - : then the trill, fountain

that in its rising jet already anticipates falling,

in promise's play........And the summer to come.

Not only the devotion of these unfolded forces,

not only the paths, not only the evening fields,

not only, after a late storm, the breathing freshness,

not only approaching sleep and a premonition, evenings...

also the nights!(Seventh Elegy.)

There could be much of promise in the unfolding of the forces at work in the world, but it all leads ultimately to night.

In the figure of the rising jet already anticipating its falling, we may in fact glimpse the Year-god,a recurring pattern in tragic art (Murray 1962), whose more frequent manifestations are in the annual cycle, inthe daily rising and setting of the sun, the diurnal cycle, in the flourishing and decay of shrubs and flowers, and in the birth, growth, achievement, waning and dissolution of the mythic hero. Only in the spectacle of the hero, who "prolongs himself, even [in] his falling" is this profoundly mythic insight turned on its head.In the Sixth Elegy, we read that,

In a few the urge to action rises so powerfully,

that they are already waiting and glowing with their heart's fullness

when the temptation to flower, like the mild night air,

touches their tender mouths, touches their eyelids:

heroes perhaps, and those chosen to vanish prematurely,

in whom Death the gardener wove different veins.

These plunge ahead: they go before their own smile,

like the team of horses in the slightly

hollowed-out relief of Karnak's victorious pharaoh.

The hero is strangely close to those who died young. Lasting

doesn't contain him.

The nearest the human creatures can come towards transcendence seems to be in the figure of the hero. These kinds of heroes exist for and by reason of the action; so free of angst,they"go before their own smile". A similar affirmation is found in Yeats's"Lapis Lazuli", where the characters act their part in a tragic play, not heeding the catastrophe that is impending,

The great stage curtain about to drop,

If worthy their prominent part in the play,

Do not break up their lines to weep.

They know that Hamlet and Lear are gay;

Gaiety transfiguring all that dread.

The Yeatsian hero has consciousness, but this does not burden the character because of the transfiguring power of gaiety.There is only action in that of Rilke: "Lasting / doesn't contain him"; and there is no fear of death in him. It does not matter to this hero if he lives only "once. Never again" (Ninth Elegy).There is a Dionysian quality in him, the Dionysian hero being an ideal form, and functioning as representative individual with the godas a kind of energy behind the mask. This being is disclosed in Nietzsche'sThe Birth of Tragedy as follows:

It is a matter of indisputable historical record that the only subject-matter of Greek tragedy, in its earliest form, was the sufferings of Dionysos, and that for a long time the only hero present on the stage was, accordingly, Dionysos. But one may also say with equal certainty that, right down to Euripides, Dionysos never ceased to be the tragic hero, and that all the famous figures of the Greek stage, 
Prometheus, Oedipus etc., are merely masks of that original hero, Dionysos. The fact that there is a deity behind all these masks is one of the essential reasons for the "ideal" quality of those famous figures which has prompted so much astonishment(51).

This god that suffers and comes back to life is clearly a powerful presence in the First Elegy, where we read, "the hero prolongs himself, even his falling / was only a pretext for being, his latest rebirth".

\section{Transference}

There remains in these poems the Kristevan figures of "double destinations" (1982: 43). In the Elegies, love and lovers are such figures with "double destinations". Love is an aspect of the human condition; at the same time it seems to signify the possibility of transcendence. Paradoxically, the manifestation of love's power to exceed itself is precisely where it is denied its object. Such is the figure of GataraStampa, "that / intenser example of love" in the First Elegy:

Have you remembered

GastaraStampasufficiently yet, that any girl,

whose lover has gone, might feel from that

intenser example of love: "Could I only become like her?"

Should not these ancient sufferings be finally

fruitful for us? Isn't it time that, loving,

we freed ourselves from the beloved, and, trembling, endured

as the arrow endures the bow, so as to be, in its flight,

something more than itself? For staying is nowhere.

Here it is the possibility of Da-sein, the capacity of love that attains disclosedness in GastaraStampa. In her, love has become 'something more than itself", a form of what the poem knows as "ancient sufferings".

Rather than see GastaraStampa's case as extraordinary, the poem's insight is that it can be "fruitful for us", towards the overcoming of the human condition itself. Hence the Speaker rhapsodizes,

Isn't it time that, loving,

we freed ourselves from the beloved, and, trembling, endured

as the arrow endures the bow, so as to be, in its flight,

something more than itself? For staying is nowhere.

On the other hand, lovers who attain the object of their love and are satisfied in them are already a class apart and are contained in the utter otherness of the second person, as opposed to the first person plural with which the Speaker identifies and on behalf of whom he speaks:

Lovers, each satisfied in the other, I ask

you about us. You grasp yourselves. Have you a sign?...

you, who under your hands

grow richer like vintage years of the vine:

who sometimes vanish, because the other

has so gained the ascendancy: I ask you of us. I know

you touch so blissfully because the caress withholds,

because the place you cover so tenderly

does not disappear: because beneath it you feel

pure duration. So that you promise eternity

almost, from the embrace (Second Elegy).

In their experience of "pure duration" and promise of "eternity / almost", lovers are in a world apart, losing consciousnessof the watchful eye of death. It is as if they now exist outsideof the human condition. But they have not escaped it: they only havewhat amounts toalmosta promise; and the prospect is almost eternity.

These things cannot be attained; and there may be false consciousness underlying the posture the Speaker catches the lovers in, since the First Elegy discloses about them that "Ah, they only hide their fate between themselves". In Elegy Five, their strivings are as hopeless as those of anyone else who is time-bound:

Angel: if there were a place we know nothing of, and there, on some unsayable carpet, lovers revealed 
what here they could never master, their high daring

figures of heart's flight,

their towers of desire, their ladders,

long since standing where there was no ground, leaning,

trembling, on each other - and mastered them,

in front of the circle of watchers, the countless, soundless dead:

Would these not fling their last, ever-saved,

ever-hidden, unknown to us, eternally

valid coins of happiness in front of the finally

truly smiling pair on the silent

carpet?

With "lovers, each satisfied in the other", the flow of emotion is caught up in a movement from the self to the other and back again. Ideally this is a movement that never attains a point of rest. The system of potentiality that is part of the identity of Da-sein, to that extent, ceases to apply to lovers. They are each other's fulfillment. Nevertheless, there is a fundamental lack even lovers are subject to, "their ladders, / long since standing where there was no ground", and something that "here they could never master". As a result, there is no question of their "finally / truly smiling".

In "reversal of a negativity into a promise" (de Man 50), love is finally what the Speaker makes use of in understanding his existence. There is a repudiation of human love in the Tenth Elegy, where the human object of human love is distanciated in the "pious capital" as Lament. But another kind of love is signified in which Earth is the object. This word moves through the poem, transforming from the name of a place, the earth, to a kind of divine form, Earth; in Lacan's phrase, "the capital Other" itself:

Earth, is it not this that you want: to rise invisibly in us? - Is that not your dream, to be invisible, one day? - Earth! Invisible!

What is your urgent command if not transformation?

Earth, beloved, I will. O, believe me, you need

no more Spring-times to win me: only one,

ah, one, is already more than my blood can stand.

Namelessly, I have been truly yours, from the first.

You were always right, and your most sacred inspiration

is that familiar Death.

See I live. On what? Neither childhood nor future

grows less.......Excess of being

wells up in my heart (Ninth Elegy).

The whole network of the Lacanian transference is played up here. For transference has two terms: "the positive transference is when you have a soft spot for the individual concerned ... and the negative transference is when you have to keep your eye on him" (2002:124). This effusion here affords a glimpse into the Speaker's unconscious:

it is to this that the transference gives us access, in an enigmatic way. It is a Gordian knot that leads us to the following conclusion - the subject is looking for his certainty (129).

The Speaker does not make use of facts in his search for certainty; it is by a movement of interpretation. Thereby he has resolved his problematic of being in the world: it consists of a relation to a "capital Other", Earth, whose urgent command, which he is more than willing to obey, is to become the mode of expression of the "capital Other". In death, this subject is certain to attain "excess of being"; he would at last become, like the arrow, the violin, the saint, GastaraStampa's love, 'something more than itself". Instead of something confronting consciousness and tending to incapacitate it, Death, although a "capital Other", is now glorified as Earth's"most sacred inspiration". For that is how Earth's dreamto "rise / invisibly in us" is realized.

\section{Conclusion}

The Tenth Elegy calls the new devotion struck in the Ninth a "fierce insight". It gives the Speaker a new orientation towards the various things and relations that have exercised his anxiety and kept him in a state of not being at home with himself, including Angels, Nights of anguish, temporality. It does not rid him of pain, 
but it changes pain from what one endures; what one fears, to the very element of existence: "place, settlement, camp, soil, dwelling". The terror of the interpreted world is hereby overcome by another interpretation.

\section{References}

[1]. R. Audi, The Cambridge dictionary of philosophy $2^{\text {nd }}$ Ed. (Cambridge, UK: UP, 1999).

[2]. P. de Man,.Allegories of reading: figural language in Rousseau, Nietzsche, Rilke, and Proust(New Haven,CT: Yale, 1979).

[3]. O. Goldsmith, Thedeserted village $<$ http://www.poetryfoundation.org/poem/173557>

[4]. T.,Gray, Elegy in the country churchyard.,http://www.bartleby.com/101/453.html>

[5]. M. Heidegger, Being and time(Albany, NY: State University of New York Press, 1996).

[6]. . Parmenides. Trans. André Schuwer and Richard Rojcewicz (Bloomington, IN: Indiana University Press,1992).

[7]. A.S. Kline, Rainer Maria Rilke: Duino Elegies. $2001<$ http://www.poetryintranslation.com/index.html $>$.Web.

[8]. N. Krauss, Reading Rilke: Reflections on the problems of translation and Duino Elegies(Boston, MA: Boston Review. 1993-2005).

[9]. J. Kristeva, Desire in language: A semiotic approach to literature and art(Oxford, UK: Blackwell, 1982)

[10]. J. Lacan, The four fundamental concepts of psycho-analysis(New York, NY: W.W. Norton, 1981).

[11]. E. Levinas, Otherwise than being or beyond essence(Dordrecht, Netherlands: Kluwer Academic Publishers, 1978).

[12]. C.H. MacKay, Soliloquy in nineteenth-century fiction(London, UK: Macmillan, 1987).

[13]. G. Murray, Aeschylus: The creator of tragedy(Oxford, UK: Clarendon, 1962).

[14]. C.M. Nichols, Primordial freedom: The authentic truth of Dasein in Heidegger's"Being and Time”,Thinking Fundamentals9(2), 2000 .

[15]. F. Nietzsche, Friedrich. The birth of tragedy and other writings(Cambridge, UK: UP, 1999)

[16]. J. Ryan, Rilke, modernism and poetic tradition(Cambridge, UK: UP,2004).

[17]. E.L. Santner, (On creaturely life (Chicago, IL: Chicago University Press, 2006).

[18]. S. Venkatchalam, In search of definitions: Literature and philosophy, Consciousness, Literature and the Arts 8(1) $2007<\mathrm{http}: / /$ www.chatbots.org/journal/consciousness_literature_and_the_arts/>

[19]. Yeats, William Butler. Lapis Lazuli.<http://www.poemhunter.com/poem/lapis-lazuli/> 